\title{
Structure and properties of strontium-doped phosphate-based glasses
}

\author{
Ensanya A. Abou Neel ${ }^{1}$, Wojciech Chrzanowski ${ }^{1}$, David M. Pickup ${ }^{2}$, \\ Luke A. O'Dell ${ }^{3}$, Nicola J. Mordan ${ }^{1}$, Robert J. Newport ${ }^{2}$, \\ Mark E. Smith ${ }^{3}$ and Jonathan C. Knowles ${ }^{1, *}$ \\ ${ }^{1}$ Division of Biomaterials and Tissue Engineering, UCL Eastman Dental Institute, \\ 256 Gray's Inn Road, London WC1X 8LD, UK \\ ${ }^{2}$ School of Physical Sciences, University of Kent, Canterbury CT2 7NH, UK \\ ${ }^{3}$ Department of Physics, University of Warwick, Coventry CV4 7AL, UK
}

\begin{abstract}
Owing to similarity in both ionic size and polarity, strontium $\left(\mathrm{Sr}^{2+}\right)$ is known to behave in a comparable way to calcium $\left(\mathrm{Ca}^{2+}\right)$, and its role in bone metabolism has been well documented as both anti-resorptive and bone forming. In this study, novel quaternary strontium-doped phosphate-based glasses, containing 1, 3 and $5 \mathrm{~mol} \% \mathrm{SrO}$, were synthesized and characterized. ${ }^{31} \mathrm{P}$ magic angle spinning (MAS) nuclear magnetic resonance results showed that, as the $\mathrm{Sr}^{2+}$ content is increased in the glasses, there is a slight increase in disproportionation of $Q^{2}$ phosphorus environments into $Q^{1}$ and $Q^{3}$ environments. Moreover, shortening and strengthening of the phosphorus to bridging oxygen distance occurred as obtained from FTIR. The general broadening of the spectral features with $\mathrm{Sr}^{2+}$ content is most probably due to the increased variation of the phosphate-cation bonding interactions caused by the introduction of the third cation. This increased disorder may be the cause of the increased degradation of the Sr-containing glasses relative to the Sr-free glass. As confirmed from elemental analysis, all $\mathrm{Sr}$-containing glasses showed higher $\mathrm{Na}_{2} \mathrm{O}$ than expected and this also could be accounted for by the higher degradation of these glasses compared with Sr-free glasses. Measurements of surface free energy (SFE) showed that incorporation of strontium had no effect on SFE, and samples had relatively higher fractional polarity, which is not expected to promote high cell activity. From viability studies, however, the incorporation of $\mathrm{Sr}^{2+}$ showed better cellular response than $\mathrm{Sr}^{2+}$-free glasses, but still lower than the positive control. This unfavourable cellular response could be due to the high degradation nature of these glasses and not due to the presence of $\mathrm{Sr}^{2+}$.
\end{abstract}

Keywords: phosphate-based glasses; biocompatibility; surface free energy; ion release; FTIR spectroscopy; nuclear magnetic resonance

\section{INTRODUCTION}

Phosphate-based glasses (PBGs) are inorganic polymers composed of $\mathrm{PO}_{4}^{3-}$ tetrahedra that form the backbone of the structure and metal cations that charge balance the phosphate chains (Knowles et al. 2001; Skelton et al. 2007). Glasses can be prepared containing various metal oxides such as $\mathrm{CuO}$ (Abou Neel et al. 2005a), $\mathrm{Fe}_{2} \mathrm{O}_{3}$ ( $\mathrm{Yu}$ et al. 1997; Ahmed et al. 2004; Abou Neel et al. 2005b), $\mathrm{Al}_{2} \mathrm{O}_{3}$ (Shah et al. 2005), $\mathrm{TiO}_{2}$ (Rajendran et al. 2006; Abou Neel et al. 2007; Abou Neel \& Knowles 2008) or ZnO (Salih et al. 2007; Abou Neel et al. 2008) to suit the end applications. Furthermore, Drake and Allen found that PBGs with a suitable composition dissolve in water with a zeroorder rate, and, by tailoring the composition further, it was possible to produce glasses with stabilities ranging from those that would completely degrade in

*Author for correspondence (j.knowles@eastman.ucl.ac.uk). water in a few hours to those that are stable for years (Drake 1985; Drake \& Allen 1985).

PBGs containing $\mathrm{Ca}^{2+}$ and $\mathrm{Na}^{+}$ions have potential applications in both soft- and hard-tissue engineering, since the ions released from these glasses are natural constituents of the human body and are therefore tolerated by it (Knowles 2003). It has been shown that extracts from the less soluble glass compositions (i.e. glasses with high calcium oxide content) enhanced cell proliferation and upregulated gene expression (Franks et al. 2002; Bitar et al. 2004). Moreover, the cells were able to attach, spread and proliferate in a manner comparable to the positive control along with the formation of a collagen-rich mineralized matrix (Gough et al. 2002). It has been reported that calcium ions play a key role in cell activation mechanisms, thereby controlling many growth-associated processes and functional activities of cells (Salih et al. 2000). 
Table 1. Glass compositions (including abbreviation used in the text hereafter), processing temperatures, density and glass transition temperature.

glass composition $(\mathrm{mol} \%)$

properties

\begin{tabular}{llllllll} 
& & & & & phosphorus & strontium & \\
glass code & notation & calcium oxide & sodium oxide & pentoxide & & $\rho\left(\mathrm{g} \mathrm{cm}{ }^{-3}\right)$ & $T_{\mathrm{g}}\left({ }^{\circ} \mathrm{C}\right)$ \\
\hline P50C30N20 & CNP & 30 & 20 & 50 & 0 & $2.58 \pm 0.00$ & $383 \pm 0.7$ \\
P50C30N19Sr1 & CNPSr1 & 30 & 19 & 50 & 1 & $2.59 \pm 0.01$ & $391 \pm 6$ \\
P50C30N17Sr3 & CNPSr3 & 30 & 17 & 50 & 3 & $2.60 \pm 0.00$ & $421 \pm 4$ \\
P50C30N15Sr5 & CNPSr5 & 30 & 15 & 50 & 5 & $2.62 \pm 0.02$ & $428 \pm 3$ \\
\hline
\end{tabular}

Physiologically, strontium and calcium are remarkably similar; they are both absorbed in the gastrointestinal tract, concentrated in bone and excreted primarily in urine (Wren et al. 2008). One of the mechanisms of strontium incorporation into bone involves ionic exchange with bone calcium. Owing to these similarities, strontium is currently used in bone therapies (Llinas et al. 2006). For example, strontium ranelate (SR) is marketed under the name of Protelos, Osseor, Protos, Bivalos, Protaxos and Ossum, and used to treat osteoporosis. It has been shown that SR strengthens bone, increases bone mass and density and lessens the possibility of vertebral and hip fracture in elderly women. This has been attributed to the fact that the human body absorbs strontium as if it were calcium. Since strontium has higher atomic weight than calcium, this accounts for the increasing bone density (Meunier et al. 2004; Reginster et al. 2005). Moreover, the radioactive isotopes of strontium $\left({ }^{89} \mathrm{Sr}\right.$ and $\left.{ }^{85} \mathrm{Sr}\right)$ are used to treat scattered painful bone metastases that affect two-thirds of patients with advanced and metastatic cancers (Giammarile et al. 1999; Saarto et al. 2002).

In this study, calcium phosphate glasses containing strontium oxide for potential use in bone tissue regeneration have been prepared. Starting with a base composition of $(\mathrm{CaO})_{0.3}\left(\mathrm{Na}_{2} \mathrm{O}\right)_{0.2}\left(\mathrm{P}_{2} \mathrm{O}_{5}\right)_{0.5}$, the $\mathrm{Na}_{2} \mathrm{O}$ was replaced with 1, 3 and $5 \mathrm{~mol} \% \mathrm{SrO}$. The objective of this study was to evaluate the effect of strontium oxide additions on the structure (X-ray powder diffraction, ${ }^{23} \mathrm{Na}$ and ${ }^{31} \mathrm{P}$ magic angle spinning (MAS) nuclear magnetic resonance (NMR) and FTIR spectroscopies), bulk (density, thermal analysis, degradation and ion release), and surface properties (wettability, surface free energy (SFE) and biocompatibility) of these glasses.

\section{EXPERIMENTAL}

\subsection{Glass preparation}

Glass rods of $15 \mathrm{~mm}$ diameter were prepared as per the compositions given in table 1 . Sodium dihydrogen orthophosphate $\left(\mathrm{NaH}_{2} \mathrm{PO}_{4}\right)$, calcium carbonate $\left(\mathrm{CaCO}_{3}\right)$, phosphorus pentoxide $\left(\mathrm{P}_{2} \mathrm{O}_{5}\right)$ and strontium carbonate $\left(\mathrm{SrCO}_{3} ; \mathrm{BDH}\right.$, Poole, UK) were used as precursors (all chemicals were above $98 \%$ purity). These precursors were weighed out and placed into a Pt/10\% Rh crucible (Type 71040, Johnson Matthey, Royston, UK). The crucible and contents were heated in a furnace (Carbolite, RHF 1500, Sheffield, UK) at $1100^{\circ} \mathrm{C}$ for 1 hour. The resultant melt was then poured into a preheated split graphite mould that was in turn placed in an annealing furnace at $350^{\circ} \mathrm{C}$ for 1 hour to remove any residual stresses in the glass. The mould was then allowed to cool slowly to room temperature in the annealing furnace overnight. The rods were cut into discs of approximately $1 \mathrm{~mm}$ thickness using a Testbourne diamond saw with methanol as a coolant/lubricant.

Powdered samples for thermal and structural characterization were prepared by grinding pieces of glass using a zirconia mill.

\subsection{Structural characterization}

2.2.1. X-ray powder diffraction. The powdered samples were annealed in a ceramic pot from room temperature to the crystallization temperature, obtained from the differential thermal analyser, at a heating rate of $20^{\circ} \mathrm{C} \min ^{-1}$ using Lenton Furnace (Lenton Thermal Designs LTD, UK). The temperature was maintained at that temperature for 3 hours to ensure proper crystallization, and finally it was reduced to room temperture at the same rate used for heating. X-ray diffraction (XRD) data for these crystallized samples were collected on a Bruker D8 Advance diffractometer (Brüker, UK) in flat-plate geometry, using Ni-filtered $\mathrm{Cu} \mathrm{K} \alpha$ radiation and a Bruker Lynx Eye detector. The X-ray patterns were measured from 10 to $100^{\circ} 2 \theta$ with a step size of $0.02^{\circ}$ and a count time of $0.1 \mathrm{~s}$. The phases were identified using Crystallographica SearchMatch software (Oxford Cryosystems, Oxford, UK) and the International Centre for Diffraction Data (ICDD) database (vols 1-42).

2.2.2. Nuclear magnetic resonance. ${ }^{23} \mathrm{Na}$ MAS NMR experiments were conducted at $7.05 \mathrm{~T}\left({ }^{23} \mathrm{Na}\right.$ Larmor frequency $97.4 \mathrm{MHz}$ ) with a Chemagnetics Infinity Plus spectrometer, using a $4 \mathrm{~mm}$ diameter rotor spinning at $12.5 \mathrm{kHz}$. Aqueous $\mathrm{NaCl}$ was used as a reference, with the sharp resonance from this set to $0 \mathrm{ppm}$. The liquid $90^{\circ}$ pulse length was determined to be $2.5 \mu \mathrm{s}$, although a much shorter pulse length $(0.5 \mu \mathrm{s})$ was used on the solid samples. A one-pulse sequence was used, with a preacquisition delay of $7.5 \mu \mathrm{s}$ and a recycle delay of $5 \mathrm{~s}$, which was sufficient to produce fully relaxed spectra. The overall experiment time was approximately $15 \mathrm{~min}$ per sample. Certain spectra were also recorded at 14.1 T on a Bruker Avance II spectrometer with similar experimental conditions to those above. 
${ }^{31} \mathrm{P}$ MAS NMR experiments were also conducted at $7.05 \mathrm{~T}\left({ }^{31} \mathrm{P}\right.$ Larmor frequency $\left.121.5 \mathrm{MHz}\right)$ using a $4 \mathrm{~mm}$ diameter rotor spinning at $12.5 \mathrm{kHz}$. Solid $\mathrm{NH}_{4} \mathrm{H}_{2} \mathrm{PO}_{4}$ was used as a secondary reference compound and the signal from this set to $0.9 \mathrm{ppm}$. A pulse length of $1.5 \mu \mathrm{s}$ was used (corresponding to an approx. $30^{\circ}$ tip angle), with a pre-acquisition delay of $7.5 \mu$ s and a recycle delay of $5 \mathrm{~s}$. Overall experiment time was approximately 10 min per sample.

All NMR spectra were subsequently processed using Spinsight and fitted using either dmfit2007 (Massiot et al. 2002) or QuadFit (Kemp 2004).

2.2.3. FTIR spectroscopy. FTIR spectra were recorded in transmission mode on a Biorad FTS175C spectrometer controlled by Win-IR software. Samples were diluted in dry $\mathrm{KBr}$ and scanned in the range of 4000$450 \mathrm{~cm}^{-1}$. Each spectrum was the result of summing 64 scans.

2.2.4. Elemental analysis. The crystalline powdered samples were carbon coated before being examined under a JEOL 5410LV scanning electron microscope (JEOL UK Ltd, UK) equipped with an INCA 300, EDX System (Oxford, UK) energy dispersive X-ray spectroscopy accessory. The electron beam was produced with a $10 \mathrm{kV}$ accelerating voltage and directed at the coated specimens. X-rays, produced by the elements in the specimen, were directed to the liquid nitrogen-cooled detector that allowed the identification of elements on the basis of their characteristic $\mathrm{X}$-ray energies.

\subsection{Bulk glass characterization}

2.3.1. Density measurements. Density measurements were conducted in triplicate on each sample by the Archimedes method, using an analytical balance (Mettler Toledo, UK) with an attached density kit. Owing to the soluble nature of the glass compositions investigated, ethanol was used as the immersion liquid for these measurements.

2.3.2. Thermal characterization. The glass transition temperature $\left(T_{\mathrm{g}}\right)$ was determined using a Pyris Diamond DSC (DIAMDSC, Perkin-Elmer Instruments, Shelton, USA). Moreover, crystallization temperature $\left(T_{\mathrm{c}}\right)$ and melting temperature $\left(T_{\mathrm{m}}\right)$ were also carried out using a Setaram Differential Thermal Analyser (TG DTA/DSC Labsys, Setaram, Caluire, France) as described previously (Abou Neel et al. 2008).

2.3.3. Degradation studies. The surface area of the glass discs was calculated from the dimensions measured with Mitutoyo Digimatic Vernier Callipers. Glass discs were placed in glass bottles containing $25 \mathrm{ml}$ of highpurity water with $\mathrm{pH}$ adjusted with few drops of $\mathrm{NH}_{4} \mathrm{OH}$ to $7 \pm 0.2$. At various time points $(0,1,4,7,11$ and 15 days), the solution was removed for ion release analysis. Then the discs were taken out of their respective containers, and excess moisture was removed by blotting the discs dry with tissue paper before weighing. The discs were then placed in a fresh solution of deionized water and placed back into the incubator at $37^{\circ} \mathrm{C}$. These studies were conducted in triplicate, and the data plotted as cumulative degradation, i.e. percentage weight loss per unit area, as a function of time for the various glass compositions.

2.3.4. Ion release measurements. Ion release studies were simultaneously conducted, and the medium was analysed for cation $\left(\mathrm{Ca}^{2+}, \mathrm{Na}^{+}\right.$and $\left.\mathrm{Sr}^{2+}\right)$ and anion $\left(\mathrm{PO}_{4}^{3-}, \mathrm{P}_{2} \mathrm{O}_{7}^{4-}, \mathrm{P}_{3} \mathrm{O}_{9}^{3-}\right.$, and $\left.\mathrm{P}_{3} \mathrm{O}_{10}^{5-}\right)$ release. All ion release studies were carried out using ion chromatography (Dionex, Surey, UK) except for $\mathrm{Sr}^{2+}$ where inductively coupled plasma mass spectrometry (ICPMS, Spectromass 2000, Kleve, Germany) was used. Owing to the much greater expected concentration of ions, samples were diluted in deionized water $\left(18 \mathrm{M} \Omega \mathrm{cm}^{-1}\right)$. The final cumulative concentration was calculated from the results of the measurements taking into account the dilution factor (Ahmed et al. 2005).

2.3.5. $p H$ measurements. At each time point, $\mathrm{pH}$ measurements were taken after transferring the glass discs to a fresh solution (deionized water, $\mathrm{pH} 7 \pm 0.2$ ). The measurements were collected using a Hanna Instruments $\mathrm{pH} 211$ Microprocessor $\mathrm{pH}$ meter (BDH, UK) with attached glass combination $\mathrm{pH}$ electrode (BDH, UK). The $\mathrm{pH}$ electrode was calibrated using pH calibration standards (Colourkey Buffer Solutions. BDH, UK). The degradation studies and preparation of the standard solutions described above were conducted using high-purity water. This was obtained from a PURELAB UHQ-PS system (Elga Labwater, UK), which purified the water to a level of $18.2 \mathrm{M} \Omega \mathrm{cm}^{-1}$ resistivity.

\subsection{Substrate surface characterization}

2.4.1. Wettability and SFE. Assessment of the surface wettability of the glasses was performed using the sessile drop method using a KSV Optic Contact Angle Meter CAM200. Contact angle measurements were conducted at room temperature with three different liquids: deionized water; diiodomethane (Sigma); and formamide (Sigma). Prior to the measurements, the surface of the samples was polished to a mirror finish using $\mathrm{SiC}$ paper (No. 4000) to avoid the influence of the roughness on the wettability and then cleaned with methanol in an ultrasonic bath for 10 min before drying with compressed air. Measurements for each liquid/ sample combination were performed in triplicate.

SFEs were calculated from the contact angle using two methods: geometric mean method (Owens-Wendt, OW) and the acid-base method (van Oss-Good, VO). For all samples, dispersive $\left(\gamma^{\mathrm{d}}, \gamma^{\mathrm{LW}}\right)$, polar $\left(\gamma^{\mathrm{p}}\right)$, acidbase $\left(\gamma^{\mathrm{ab}}\right)$, acidic $\left(\gamma^{\mathrm{a}}\right)$ and basic $\left(\gamma^{\mathrm{b}}\right)$ components were calculated.

2.4.2. Cell viability. Human osteosarcoma cells (HOS) were used to obtain a preliminary estimate of biological 
(a)

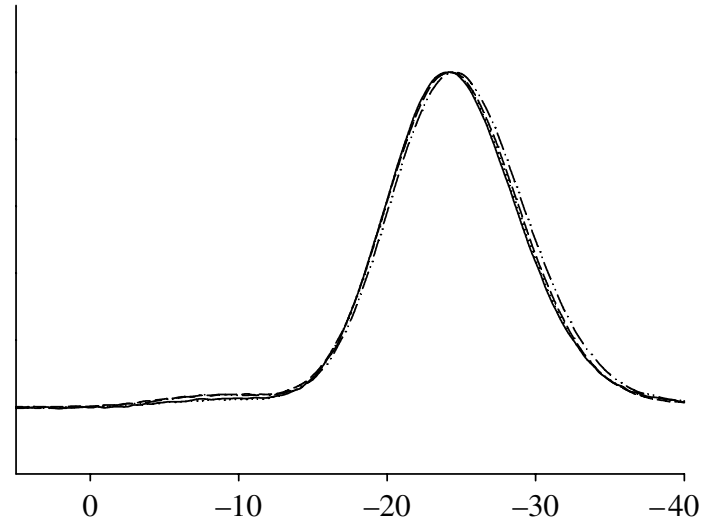

(c)

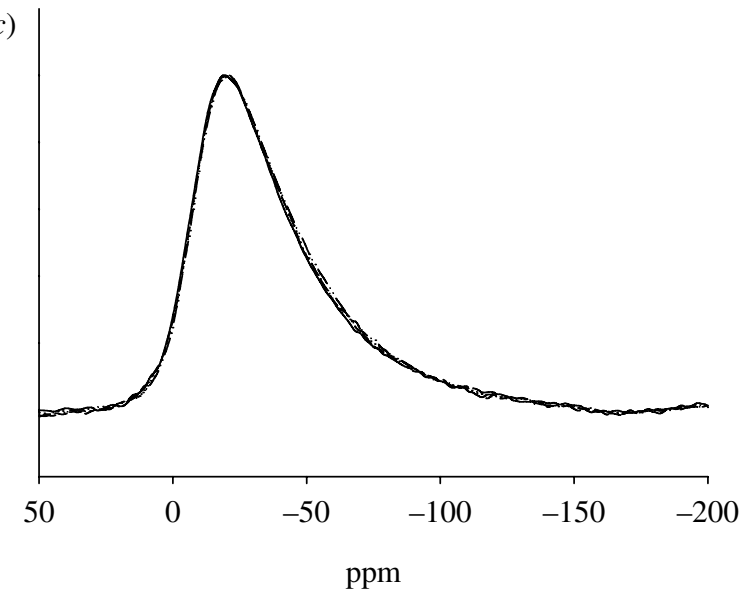

(b)

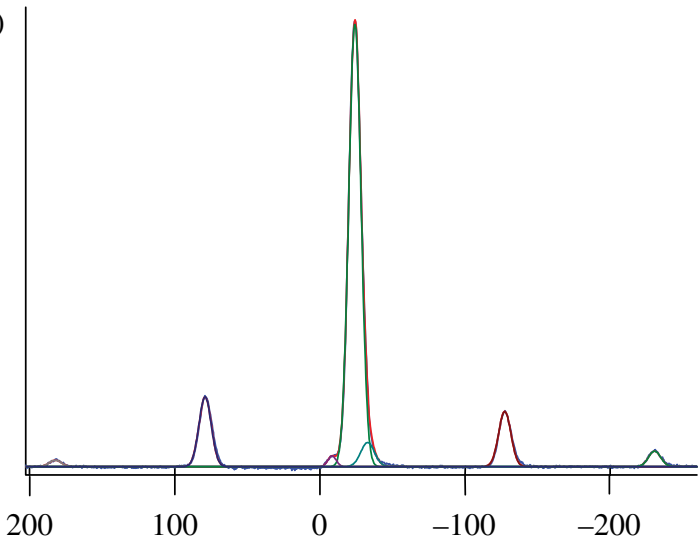

(d)

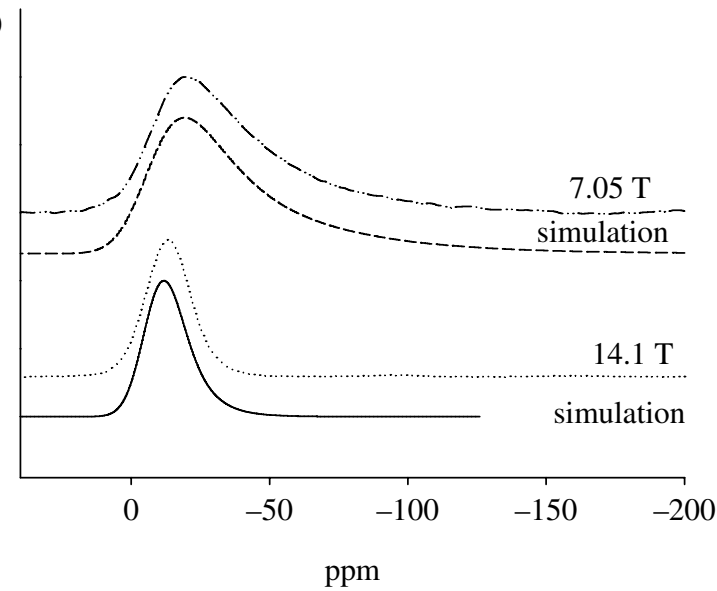

Figure 1. (a) The overlaid ${ }^{31} \mathrm{P}$ MAS NMR spectra obtained from the glass samples, with the horizontal frequency scale expanded to show only the isotropic region, $(b)$ fit of the ${ }^{31} \mathrm{P}$ MAS NMR spectrum obtained from the CNP glass, with spinning sidebands visible on either side of the centre bands, $(c)$ the ${ }^{23} \mathrm{Na}$ MAS NMR spectra obtained from the PBGs at $7.05 \mathrm{~T}$ and $(d)$ experimental and simulated spectra of the CNP glass at 14.1 and 7.05 T. $(a, c, d)$ Solid line, CNP; dotted line, CNPSr1; dashed line, CNPSr3; dot-dashed line, CNPSr5.

compatibility of these glasses using live-dead staining and confocal laser scanning microscopy (CLSM, BioRad, USA) as described previously (Abou Neel et al. 2007; Abou Neel \& Knowles 2008).

\subsection{Statistical analysis}

The Student's t-test (Abou Neel et al. 2007) was used to analyse the significance of changes in density and the glass transition temperature as a function of $\mathrm{SrO}$ content. Significance was set at a 0.05 level, and all statistical analyses carried out using the SPSS system for Windows (SPSS v. 12.0.1).

\section{RESULTS}

\subsection{Structural characterization}

3.1.1. X-ray powder diffraction. A sodium calcium phosphate $\left(\mathrm{NaCa}\left(\mathrm{PO}_{3}\right)_{3}-23-669\right)$ phase was detected with XRD for all glass compositions, after crystallization. Strontium phosphate $\left(\mathrm{Sr}_{3}\left(\mathrm{PO}_{4}\right)_{2}-32-1251\right)$ was also identified as a minor phase in the CNPSr5 glass.

3.1.2. Nuclear magnetic resonance. Figure $1 a$ shows the overlaid ${ }^{31} \mathrm{P}$ MAS NMR spectra obtained from the glass samples, with the horizontal frequency scale expanded about the isotropic region such that the spinning sidebands are not shown. Each spectrum was fitted using Gaussian peaks centred at approximately -8 , -24 and $-32 \mathrm{ppm}$, representing $Q^{1}, Q^{2}$ and $Q^{3}$ phosphorus environments, respectively ( $Q^{n}$ denoting a phosphate tetrahedron with $n$ bridging oxygens). In order to obtain the relative abundances of each of these $Q^{n}$ species, the intensities of these peaks were fitted (along with the spinning sidebands). An example of such fitting is shown in figure $1 b$ and the results of such fitting are given in table 2 .

Figure $1 c$ shows the overlaid ${ }^{23} \mathrm{Na}$ MAS NMR spectra obtained from the glasses. All the spectra show a single broad peak that remains effectively constant as the $\mathrm{SrO}$ content increases. This shape is characteristic of sodium observed in a glass where there is a spread of quadrupolar interactions (Kohn et al. 1998; Smith \& Van Eck 1999). The multiple field data can be used to constrain things since under MAS there are effectively two residual interactions affecting the observed lineshape. There are residual second-order quadrupole effects and the spread of isotropic chemical shifts, often termed the chemical shift distribution. These interactions are, respectively, inversely and directly proportional $(\mathrm{Hz})$ to the applied magnetic field (Smith \& Van Eck 1999). The simulation employs a Gaussian distribution in the quadrupolar coupling 
Table 2. The ${ }^{31} \mathrm{P}$ MAS NMR peak parameters.

\begin{tabular}{llccc}
\hline $\begin{array}{l}\text { glass } \\
\text { code }\end{array}$ & $\begin{array}{l}Q^{n} \\
\text { species }\end{array}$ & $\begin{array}{l}\text { shift } \\
( \pm 0.5 \mathrm{ppm})\end{array}$ & $\begin{array}{l}\text { abundance } \\
( \pm 1 \%)\end{array}$ & $\begin{array}{l}\text { linewidth } \\
( \pm 1 \mathrm{ppm})\end{array}$ \\
\hline \multirow{2}{*}{ CNP } & 1 & -8.4 & 1.2 & 6.7 \\
& 2 & -24.1 & 94.5 & 10.0 \\
& 3 & -32.9 & 4.4 & 11.1 \\
CNPSr1 & 1 & -8.2 & 1.1 & 7.0 \\
& 2 & -24.1 & 93.9 & 9.8 \\
& 3 & -32.1 & 5.0 & 10.6 \\
CNPSr3 & 1 & -8.4 & 2.3 & 8.6 \\
& 2 & -24.1 & 92.1 & 9.8 \\
& 3 & -31.4 & 5.6 & 9.4 \\
CNPSr5 & 1 & -8.3 & 2.3 & 8.5 \\
& 2 & -24.4 & 91.6 & 10.0 \\
& 3 & -31.6 & 6.2 & 10.2 \\
\hline
\end{tabular}

constant $C_{\mathrm{Q}}$ (MacKenzie \& Smith 2002; full-width halfmaximum $(\mathrm{FWHM})$ of this distribution $\left.=\Delta C_{\mathrm{Q}}\right)$, which can be used as a semi-quantitative measure of disorder (O'Dell et al. 2007). An example of such fitting is shown in figure $1 d$. The spectra were simulated with a mean $C_{\mathrm{Q}}=2.4 \pm 0.1 \mathrm{MHz}, \Delta C_{\mathrm{Q}}=2.9 \pm 0.1 \mathrm{MHz}$, and an isotropic chemical shift of $-8 \pm 0.5 \mathrm{ppm}$. These parameters gave a good fit to all of the ${ }^{23} \mathrm{Na}$ MAS NMR lines in figure 1c. For simplicity, the isotropic chemical shift was kept constant, and the asymmetry parameter $\eta_{\mathrm{Q}}$ was set at 0 , although in reality a distribution in $C_{\mathrm{Q}}$ would probably mean a distribution in these parameters also.

3.1.3. FTIR spectroscopy. Figure 2 shows the FTIR spectra from the CNPSr1, CNPSr3 and CNPSr5 samples compared with CNP. As can be seen, the spectra from the strontium-containing glasses show only very subtle variation as a function of composition. However, the main change observed is a reduction in the intensity and a slight shift to higher wavenumber of the $\nu_{\text {as }}(\mathrm{P}-\mathrm{O}-\mathrm{P})$ mode (at approx. $900 \mathrm{~cm}^{-1}$ ) as the $\mathrm{Sr}^{2+}$ content increases. The other noticeable change is a general broadening of the spectral features as $\mathrm{Na}_{2} \mathrm{O}$ is replaced by $\mathrm{SrO}$. Generally, the absorption bands in the above spectra can be assigned according to the data in table 3 (Byun et al. 1995; Moustafa \& El-Egili 1998; Ilieva et al. 2001; Shih \& Shiu 2007).

3.1.4. Elemental analysis. The O, P, Ca, Na and Sr were detected from all the strontium-containing glass samples. These elements were also calculated as oxides and considered in mol\% as given in table 4 . The analysis showed that there is a specific trend for the amount of Sr incorporated in the structure with less than 1 per cent error. This trend correlated with the actual $\mathrm{Sr}$ content included in the glass structure. It was also observed that the weight $\%$ of both $\mathrm{P}$ and $\mathrm{Ca}$ remained relatively constant for all studied glass composition. The weight\% of $\mathrm{Na}$, however, is changing with the composition. From the calculated oxides, it seems that both $\mathrm{P}_{2} \mathrm{O}_{5}$ and $\mathrm{SrO}$ are as expected; however, there is more $\mathrm{Na}_{2} \mathrm{O}$ and less $\mathrm{CaO}$ than expected particularly for CNPSr1 and CNPSr3. Table 5

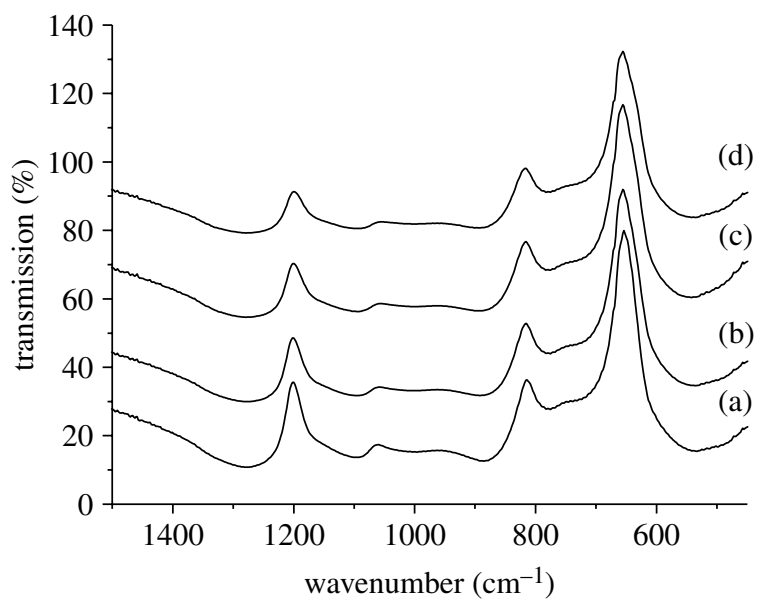

Figure 2. FTIR spectra: (a) CNP, (b) CNPSr1, (c) CNPSr3 and (d) CNPSr5.

Table 3. Infrared band assignments for the Sr-containing PBGs $(\delta$, deformation; $\nu$, stretching; s, symmetric; as, asymmetric).

\begin{tabular}{lll}
\hline & $\begin{array}{l}\text { assignment; Byun et al. (1995), } \\
\text { Moustafa \& El-Egili (1998), }\end{array}$ & associated \\
$\begin{array}{l}\text { wavenumber } \\
\left(\mathrm{cm}^{-1}\right)\end{array}$ & $\begin{array}{l}\text { Ilieva } \text { et al. (2001) and O'Dell } \\
\text { et al. }(2007)\end{array}$ & $\begin{array}{l}Q^{n} \text { (where } \\
\text { applicable) }\end{array}$ \\
\hline 540 & $\delta(\mathrm{P}-\mathrm{O}-\mathrm{P})$ & \\
725 & $\nu_{\mathrm{s}}(\mathrm{P}-\mathrm{O}-\mathrm{P})$ & \\
770 & $\nu_{\mathrm{s}}(\mathrm{P}-\mathrm{O}-\mathrm{P})$ & \\
900 & $\nu_{\text {as }}(\mathrm{P}-\mathrm{O}-\mathrm{P})$ & $Q^{2}$ \\
1000 & $\nu_{\mathrm{s}}\left(\mathrm{PO}_{3}\right)^{2-}$ & $Q^{1}$ \\
1100 & $\nu_{\text {as }}\left(\mathrm{PO}_{3}\right)^{2-}$ & $Q^{1}$ \\
1270 & $\nu_{\text {as }}\left(\mathrm{PO}_{2}\right)^{-}$ & $Q^{2}$ \\
\hline
\end{tabular}

compares the average number of non-bridging oxygen atoms per $\mathrm{PO}_{4}^{3-}(\mathrm{NBO} / \mathrm{P})$ calculated from the compositions with those calculated from the NMR Q-speciation. These ratios were calculated using the equations

$$
\left(\frac{\mathrm{NBO}}{\mathrm{P}}\right)_{\text {composition }}=\frac{\left(2 c_{\mathrm{Ca}}+c_{\mathrm{Na}}+2 c_{\mathrm{Sr}}\right)}{c_{\mathrm{P}}},
$$

where $c_{i}$ represents the concentration of element $i$, and

$$
\left(\frac{\mathrm{NBO}}{\mathrm{P}}\right)_{\mathrm{NMR}}=\left[Q^{2}\right]+2\left[Q^{1}\right],
$$

where $Q^{n}$ is the fraction on $Q^{n}$ species. Note that these $\mathrm{NBO} / \mathrm{P}$ ratios do not include the terminal $\mathrm{P}=\mathrm{O}$ group.

Table 4. Glass composition as obtained from energy dispersive $\mathrm{X}$-ray spectroscopy.

$$
\text { composition }(\operatorname{mol} \%)
$$

\begin{tabular}{lllll}
\cline { 2 - 5 } $\begin{array}{l}\text { glass } \\
\text { code }\end{array}$ & $\mathrm{Na}_{2} \mathrm{O}$ & $\mathrm{P}_{2} \mathrm{O}_{5}$ & $\mathrm{CaO}$ & \multicolumn{1}{c}{$\mathrm{SrO}$} \\
\hline $\mathrm{CNP}$ & $24.3 \pm 2.2$ & $51.0 \pm 3.8$ & $24.8 \pm 1.6$ & - \\
$\mathrm{CNPSr} 1$ & $26.2 \pm 0.6$ & $47.7 \pm 3.5$ & $24.0 \pm 1.9$ & $2.0 \pm 1.1$ \\
CNPSr3 & $28.3 \pm 1.6$ & $45.8 \pm 4.3$ & $20.8 \pm 1.1$ & $5.2 \pm 1.6$ \\
CNPSr5 & $18.9 \pm 1.1$ & $46.0 \pm 4.9$ & $23.7 \pm 2.9$ & $11.5 \pm 1.0$ \\
\hline
\end{tabular}


Table 5. Average number of non-bridging oxygen atoms per $\mathrm{PO}_{4}^{3-}$ calculated from the elemental analysis compared with those calculated from the ${ }^{31} \mathrm{P}$ NMR results. (Note that these $\mathrm{NBO} / \mathrm{P}$ ratios do not include the terminal $\mathrm{P}=\mathrm{O}$ group.)

\begin{tabular}{lll}
\hline glass code & $\begin{array}{l}\text { NBO/P calculated from } \\
\text { composition } \pm 15 \%\end{array}$ & $\begin{array}{l}\text { NBO/P calculated } \\
\text { from NMR } \pm 1 \%\end{array}$ \\
\hline CNP & 0.96 & 0.97 \\
CNPSr1 & 1.10 & 0.96 \\
CNPSr3 & 1.18 & 0.97 \\
CNPSr5 & 1.18 & 0.96 \\
\hline
\end{tabular}

\subsection{Bulk glass characterization}

3.2.1. Density. Table 1 gives the effect of replacement of $\mathrm{Na}_{2} \mathrm{O}$ with $\mathrm{SrO}$ on the density of the glasses. The results show that introducing $\mathrm{SrO}$ into the glass causes an increase in density that correlates well with the $\mathrm{SrO}$ concentration. It should be noted, however, that the difference in density between the CNP and CNPSr1 samples is not statistically significant.

3.2.2. Thermal characterization. Table 1 gives the glass transition temperatures of the PBGs obtained from the DSC curves. As observed for the density, the $T_{\mathrm{g}}$ of the glasses also increased with increasing $\mathrm{SrO}$ content. Again, it should be noted that the differences between the $T_{\mathrm{g}}$ values for the CNP and CNPSr1 samples, and the CNPSr3 and CNPSr5 samples, are not statistically significant.

DTA provides an overview of the possible transformations that the glasses undergo at different temperatures, such as the glass transition (manifested by the first inflection in the trace), crystallization temperature (characterized by exothermic peak) and melting temperature (characterized by endothermic peak). Figure $3 a, b$ shows the DTA traces from all three glass compositions. For CNP glass (figure $3 a$ ), the trace was characterized by the presence of a single sharp crystalline peak at $600^{\circ} \mathrm{C}$ and two melting peaks at 757 and $864^{\circ} \mathrm{C}$. Crystallization of the CNPSr1 glass occurred at $650^{\circ} \mathrm{C}$ and the two melting peaks were identified at 756 and $866^{\circ} \mathrm{C}$. For CNPSr3 glasses, the crystallization peak shifted to a higher temperature $\left(683^{\circ} \mathrm{C}\right)$ and the melting peaks were observed at 750 and $894^{\circ} \mathrm{C}$. Crystallization was further retarded for the CNPSr5 glasses $\left(720^{\circ} \mathrm{C}\right)$. Furthermore, a second crystallization event was observed at $750^{\circ} \mathrm{C}$. The melting peak for this composition was also identified at higher temperature $\left(910^{\circ} \mathrm{C}\right.$; figure $\left.3 b\right)$.

3.2.3. Degradation. Figure 4 shows the cumulative degradation as weight loss per unit area as a function of time for all glass compositions. The weight loss per unit area increased with time for all samples, and the rate of weight loss increased significantly with increasing SrO. For the purpose of comparison, the degradation rates were estimated by fitting the degradation curves with a straight line. Using this method, values of $6.4 \pm 0.25,29.55 \pm 4.03,19.0 \pm 4.34$ and $14 \pm 4.46 \times 10^{-3} \% \mathrm{~mm}^{-2} \mathrm{~h}^{-1}$ were obtained for
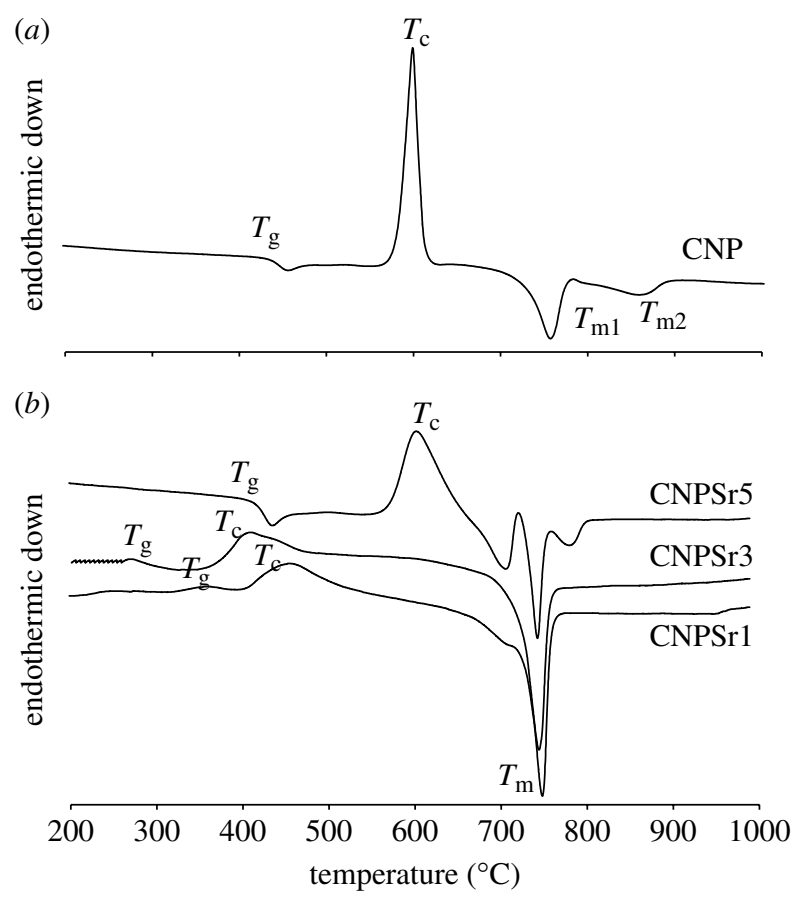

Figure 3. $(a, b)$ DTA traces from PBGs doped with different concentrations of strontium oxide. (a) Solid line, $0 \mathrm{~mol} \% \mathrm{TiO}_{2}$.

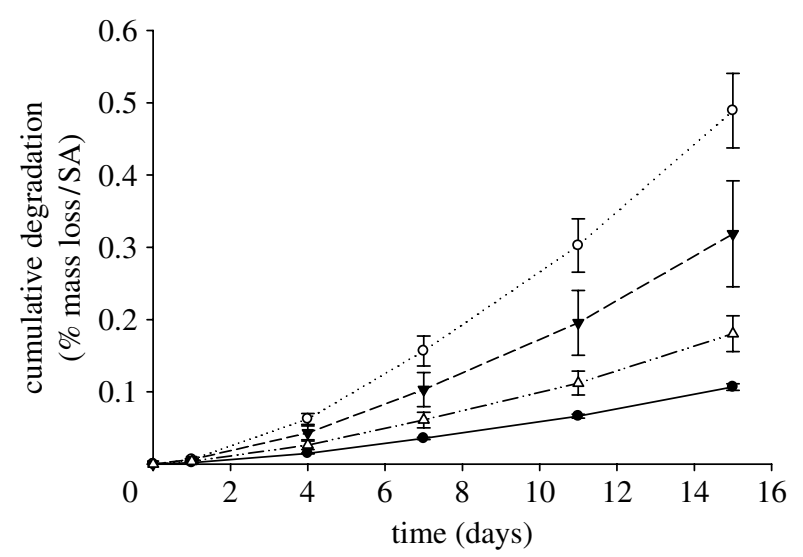

Figure 4. Degradation profiles (i.e. presented as cumulative weight loss \%/surface area) for the CNPSr1 (opened circles), CNPSr3 (filled down triangles) and CNPSr5 (open up triangles) glasses compared with the CNP (filled circles) control glass as a function of time.

the CNP, CNPSr1, CNPSr3 and CNPSr5 compositions, respectively. Interestingly, the degradation rate increased with the addition of $1 \mathrm{~mol} \% \mathrm{SrO}$ and then decreased with further addition of SrO.

3.2.4. Cumulative ion release measurements. Cumulative cation release measurements The release profiles for $\mathrm{Na}^{+}$ions follow exactly the same trend as the degradation with the CNPSr1 composition showing the highest level of release followed by the CNPSr3, CNPSr5 and CNP compositions in that order. For the $\mathrm{Ca}^{2+}$ release, however, the CNPSr1 composition showed the highest level of release followed by the CNP, CNPSr3 and CNPSr5 compositions in that order. It was also observed that the CNPSr1 composition released the highest levels of both $\mathrm{Na}^{+}$and $\mathrm{Ca}^{2+}$ 
cations. The release rates were estimated by fitting a straight line of the form $y=m x$ through the data.

The estimated release rates for $\mathrm{Sr}^{2+}$ also correlated well with the $\mathrm{SrO}$ content of the glasses (figure 5).

Cumulative anion release measurements The cumulative release of four different anionic species: orthophosphate $\left(\mathrm{PO}_{4}^{3-}\right)$; cyclic trimetaphosphate $\left(\mathrm{P}_{3} \mathrm{O}_{9}^{3-}\right)$; pyrophosphate $\left(\mathrm{P}_{2} \mathrm{O}_{7}^{4-}\right)$; and linear polyphosphate $\left(\mathrm{P}_{3} \mathrm{O}_{10}^{5-}\right)$ was identified. Of these anions, $\mathrm{P}_{3} \mathrm{O}_{9}^{3-}$ was released in the largest quantities followed by $\mathrm{PO}_{4}^{3-}, \mathrm{P}_{3} \mathrm{O}_{10}^{5-}$ and $\mathrm{P}_{2} \mathrm{O}_{7}^{4-}$ in that order. The release rate for each anionic species was also calculated by linear fitting of the data and presented in figure 5 . The Sr-containing glasses all exhibited higher levels of $\mathrm{PO}_{4}^{3-}$ and $\mathrm{P}_{2} \mathrm{O}_{7}^{4-}$ release than the CNP control glasses. In the case of the $\mathrm{P}_{3} \mathrm{O}_{9}^{3-}$ anion, the Sr-containing glasses all exhibited a lower release rate than the CNP control glasses. The CNP and CNPSr5 compositions released $\mathrm{P}_{3} \mathrm{O}_{10}^{5-}$ ions at the highest and lowest rates, respectively, with the CNPSr1 and CNPSr3 compositions releasing this anion at approximately the same rate midway between those of the other two compositions.

3.2.5. $p H$ analysis. Figure 6 shows the $\mathrm{pH}$ changes of the deionized water used for the degradation studies as a function of time for all glass compositions. For all samples, the dissolution medium reached a constant $\mathrm{pH}$ after 4 days. CNPSr1 glasses displayed the minimum (4.2) $\mathrm{pH}$ value of the surrounding medium. The lowest reduction in $\mathrm{pH}$ was observed for $\mathrm{CNP}$ glasses where the medium reaches a $\mathrm{pH}$ of $4.92 \pm 0.06$. The $\mathrm{pH}$ for the medium surrounding the CNPSr3 and CNPSr5 glasses settled at approximately 4.6 .

\subsection{Substrate surface characterization}

3.3.1. Wettability and SFE. Results of SFE calculated on the basis of the OW method (KSV Instruments 2007) are shown in figure $7 a$. The total SFE for all samples was $70 \mathrm{mN} \mathrm{m}^{-1}$. The dispersive component $\left(\gamma^{\mathrm{d}}\right)$ was approximately $37 \mathrm{mN} \mathrm{m}^{-1}$ for CNP and CNPSr5 samples, while for CNPSr1 and CNPSr3 glasses, it was $34 \mathrm{mN} \mathrm{m}^{-1}$. The polar component $\left(\gamma^{\mathrm{p}}\right)$ was at the level of $34 \mathrm{mN} \mathrm{m}^{-1}$ for CNP and CNPSr5 samples and $36 \mathrm{mN} \mathrm{m}^{-1}$ for CNPSr1 and CNPSr3 samples. In addition, the fractional polarity (FP) was calculated as $\mathrm{FP}=\gamma^{\mathrm{p}} /\left(\gamma^{\mathrm{p}} / \gamma^{\mathrm{d}}\right.$; Ponsonnet et al. 2003; figure $7 b)$, but no significant variations were observed between samples.

SFE obtained from the VO method (KSV Instruments 2007) showed that the dispersive component $\left(\gamma^{\mathrm{LW}}\right)$ was the highest for CNP and CNPSr5 glasses (approx. $44 \mathrm{mN} \mathrm{m}^{-1}$ ) as shown in figure $7 c$. These glasses also had the lowest acidic $\left(\gamma^{\mathrm{a}} 0.55\right.$ and $0.65 \mathrm{mN} \mathrm{m}^{-1}$, respectively) and acid-base components $\left(\gamma^{\mathrm{ab}} 8.5\right.$ and $10 \mathrm{mN} \mathrm{m}^{-1}$, respectively) as shown in figure $7 d$. For the CNPSr1 and CNPSr3 glasses, these components were as follows: acidic $\left(\gamma^{\mathrm{a}}\right) 0.79$ and $0.87 \mathrm{mN} \mathrm{m}^{-1}$, respectively, and acid-base $\left(\gamma^{\mathrm{ab}}\right) 12.1$ and $13.2 \mathrm{mN} \mathrm{m}^{-1}$, respectively, as shown in figure $7 d$.
3.3.2. Cell viability. Figure 8 shows CLSM images of live/dead stained HOS attached to the surfaces of the tested glass compositions and the positive control after 24 hours of culture. As can be seen from these images, the cells showed relatively better response on strontium-containing glass surfaces than strontiumfree glasses. This could be detected from both the number and morphology of cells where higher number of cells were observed on the surface of strontiumcontaining glass, particularly CNPSr1 and CNPSr3. The cells had rounded morphology when they attached to CNP glasses compared with the more flattened morphology when they grow on all strontiumcontaining glasses. Moreover, both CNP and CNPSr5 showed lower number of cells attached to both surfaces. However, CNPSr1 and CNPSr3 showed relatively more cells attached to their surfaces in a manner comparable to the positive control up to the time of the experiment. After 24 hours, no cells were detected on all glass surfaces.

\section{DISCUSSION}

$\mathrm{Sr}^{2+}$ is known to behave in a comparable way to $\mathrm{Ca}^{2+}$, which has similar ionic size and polarity to $\mathrm{Ca}^{2+}$ (Wren et al. 2008). Its role in bone metabolism has been well documented; it has both anti-resorptive and bone-forming effects that can be used to decrease the risk of fracture in postmenopausal women when administered as SR, marketed as Protelos. In the form of $\mathrm{SR}, \mathrm{Sr}^{2+}$ can induce bone cell replication and collagen synthesis, while also inhibiting the activity of osteoclasts (Marie 2005).

The purpose of this study was to investigate the possibility of incorporation of $\mathrm{Sr}^{2+}$ into PBGs for potential applications in bone tissue engineering. The effect of incorporation of $\mathrm{Sr}^{2+}$ on the glass structure, degradation, associated ion release and $\mathrm{pH}$ changes that affect the surrounding environment were studied.

The XRD data revealed that, after crystallization by heating to $T_{\mathrm{c}}$, all the glass compositions contained the same phase $\left(\mathrm{NaCa}\left(\mathrm{PO}_{3}\right)_{3}-23-669\right)$; the only strontiumcontaining phase $\left(\mathrm{Sr}_{3}\left(\mathrm{PO}_{4}\right)_{2}-32-1251\right)$ was identified as a minor component in the CNPSr5 sample.

The dominance of the $Q^{2}$ peak in the ${ }^{31} \mathrm{P}$ MAS NMR spectra was to be expected since phosphate glasses containing $50 \mathrm{~mol} \% \quad \mathrm{P}_{2} \mathrm{O}_{5}$ are well known to consist almost entirely of infinite chains or rings of phosphate tetrahedra (Brow et al. 1990). Increasing the SrO content resulted in a decrease in $Q^{2}$ species in the glasses with both the $Q^{1}$ and $Q^{3}$ species increasing. This is perhaps evidence of disproportionation of $Q^{2}$ species according to the relationship $2 Q^{2} \rightarrow Q^{1}+Q^{3}$. Such disproportionation has previously been observed in metaphosphate glasses containing sodium and calcium (Fletcher et al. 1993; Velli et al. 2005), and, in this case, shows a slight increase with $\mathrm{SrO}$ content. No linear trend in either the chemical shift or the linewidth of the ${ }^{31} \mathrm{P}$ MAS NMR peaks occurs as the $\mathrm{Sr}^{2+}$ content was increased. However, the lack of any change in the ${ }^{23} \mathrm{Na}$ MAS NMR spectra indicates that the $\mathrm{Sr}^{2+}$ had no appreciable effect on the average sodium environment. 


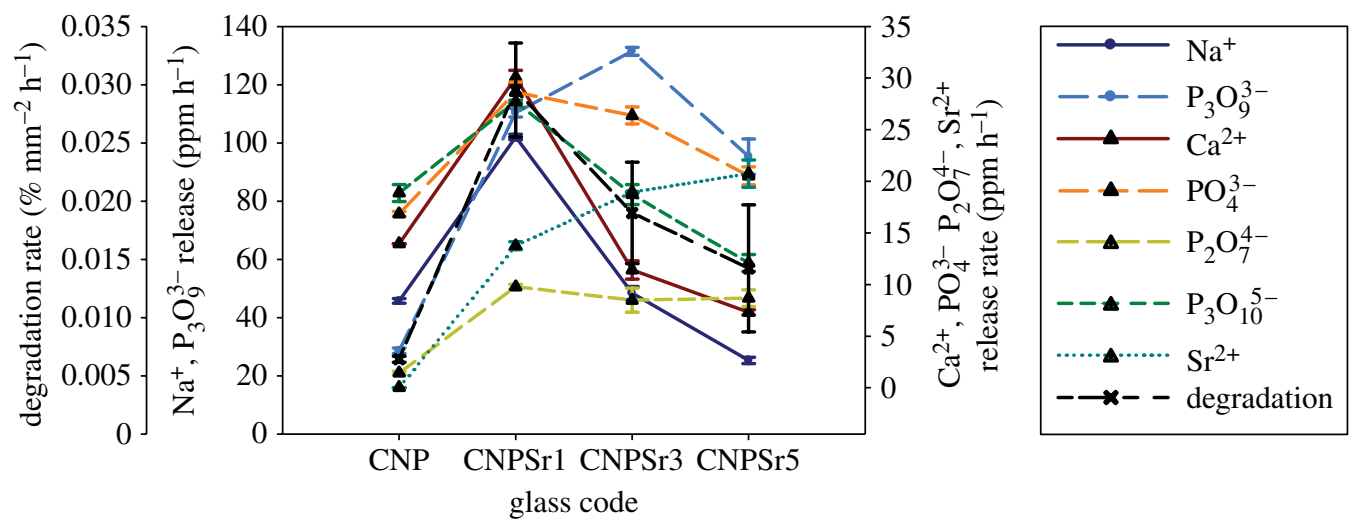

Figure 5. Rate of degradation, and ion release for different cationic and anionic species as a function of the glass composition. The rate was estimated by fitting a straight line of the form $y=m x$ through the data.

FTIR spectra from the strontium-containing glasses showed only very subtle variation as a function of composition: this was to be expected since substitution of $\mathrm{Na}_{2} \mathrm{O}$ by $\mathrm{SrO}$ does not change the $\mathrm{O} / \mathrm{P}$ ratio and hence no variation in the $Q$-speciation was expected, and the variation determined from the ${ }^{31} \mathrm{P}$ NMR is only slight. However, the cause of the observed shift in the frequency of the $\nu_{\text {as }}(\mathrm{P}-\mathrm{O}-\mathrm{P})$ mode is the replacement of $\mathrm{Na}^{+}$ions by higher field strength $\mathrm{Sr}^{2+}$ ions (Shih \& Shiu 2007). A previous neutron diffraction study of $\mathrm{CaO}-\mathrm{Na}_{2} \mathrm{O}-\mathrm{P}_{2} \mathrm{O}_{5}$ glasses (Pickup et al. 2007) demonstrated that increasing the average cation field strength by replacing $\mathrm{Na}^{+}$with $\mathrm{Ca}^{2+}$ caused a shortening of the phosphorus to bridging oxygen distance. The FTIR results suggest that a similar effect is happening here with the replacement of $\mathrm{Na}^{+}$by $\mathrm{Sr}^{2+}$ causing a shortening of the $\mathrm{P}-\mathrm{O}-\mathrm{P}$ bonding, which results in a shift in the frequency of the $\nu_{\text {as }}(\mathrm{P}-\mathrm{O}-\mathrm{P})$ mode to higher energy. The general broadening of the spectral features with $\mathrm{Sr}^{2+}$ content is most probably due to the increased variation of the phosphate-cation bonding interactions caused by the introduction of the third cation. In fact, comparing the FTIR spectrum from the CNP glass with those from the Sr-containing glasses, it can be seen that the absorption bands in the latter spectra are broader and less well resolved. This suggests that addition of just $1 \mathrm{~mol} \% \mathrm{SrO}$ causes a significant increase in disorder in bonding; it is perhaps this increased disorder that causes the increased solubility of the Sr-containing glasses compared with the CNP glass. Glasses are metastable with respect to the crystalline state; they are also disordered relative to their crystals. From this, it can be inferred that there is some instability associated with disorder, since the solubility is a trade-off between the energy required to dissociate the structure and the energy released upon hydration of the resultant ions. Therefore, it seems reasonable to suggest that a more disordered, less stable structure may be more soluble.

The NBO/P ratios calculated from the elemental analysis are in close agreement with those calculated from the ${ }^{31} \mathrm{P}$ NMR results, if one takes into consideration the errors associated with the two sets of data. The Sr-containing glasses, CNPSr1 and CNPSr3 in particular, showed higher $\mathrm{Na}_{2} \mathrm{O}$ than expected, and this

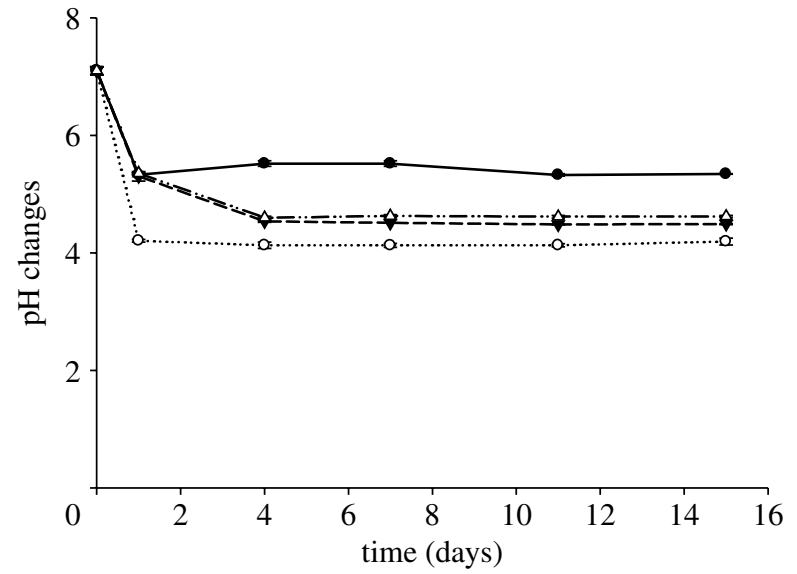

Figure 6. Changes in $\mathrm{pH}$ of deionized water as a function of time for the CNPSr1 (open circles), CNPSr3 (filled down triangles), and CNPSr5 (open up triangles) glasses compared with the CNP (filled circles) control glass.

could also explain the fact that these glasses showed a higher degradation rate than Sr-free glasses.

The observed increase in density with incorporation of $\mathrm{SrO}$ into the glass structure could be attributed to the much higher density of $\operatorname{SrO}\left(4.7 \mathrm{~g} \mathrm{~cm}^{-3}\right)$ than that of $\mathrm{Na}_{2} \mathrm{O}\left(2.27 \mathrm{~g} \mathrm{~cm}^{-3}\right)$. This increase in density also correlated with an increase in the $T_{\mathrm{g}}$ and coupled with a shift in both crystallization and melting peaks to higher temperature. However, incorporation of $\mathrm{SrO}$ increased the degradation rate of these glasses. This was not expected since replacing $\mathrm{Na}_{2} \mathrm{O}$ with $\mathrm{CaO}$ in the $\mathrm{CaO}-$ $\mathrm{Na}_{2} \mathrm{O}-\mathrm{P}_{2} \mathrm{O}_{5}$ system effectively reduces the degradation (Franks et al. 2000). Incorporation of only $1 \mathrm{~mol} \%$ of SrO produced a fivefold increase in the degradation compared with glasses free from SrO. With further addition of $\mathrm{SrO}$, the solubility is reduced but still remains significantly higher than that of SrO-free glasses.

The results of the ion release study here reflected the degradation behaviour of the glasses with all the SrOcontaining glasses exhibiting greater ion release than the SrO-free glasses as shown in figure 5. Comparing the release of different cations, $\mathrm{Na}^{+}$ions were released at higher levels than $\mathrm{Ca}^{2+}$. It is notable that even though the $\mathrm{CNP}$ glass contained the highest $\mathrm{Na}_{2} \mathrm{O}$ content, it released less $\mathrm{Na}^{+}$than the $\mathrm{SrO}$-containing glasses. 

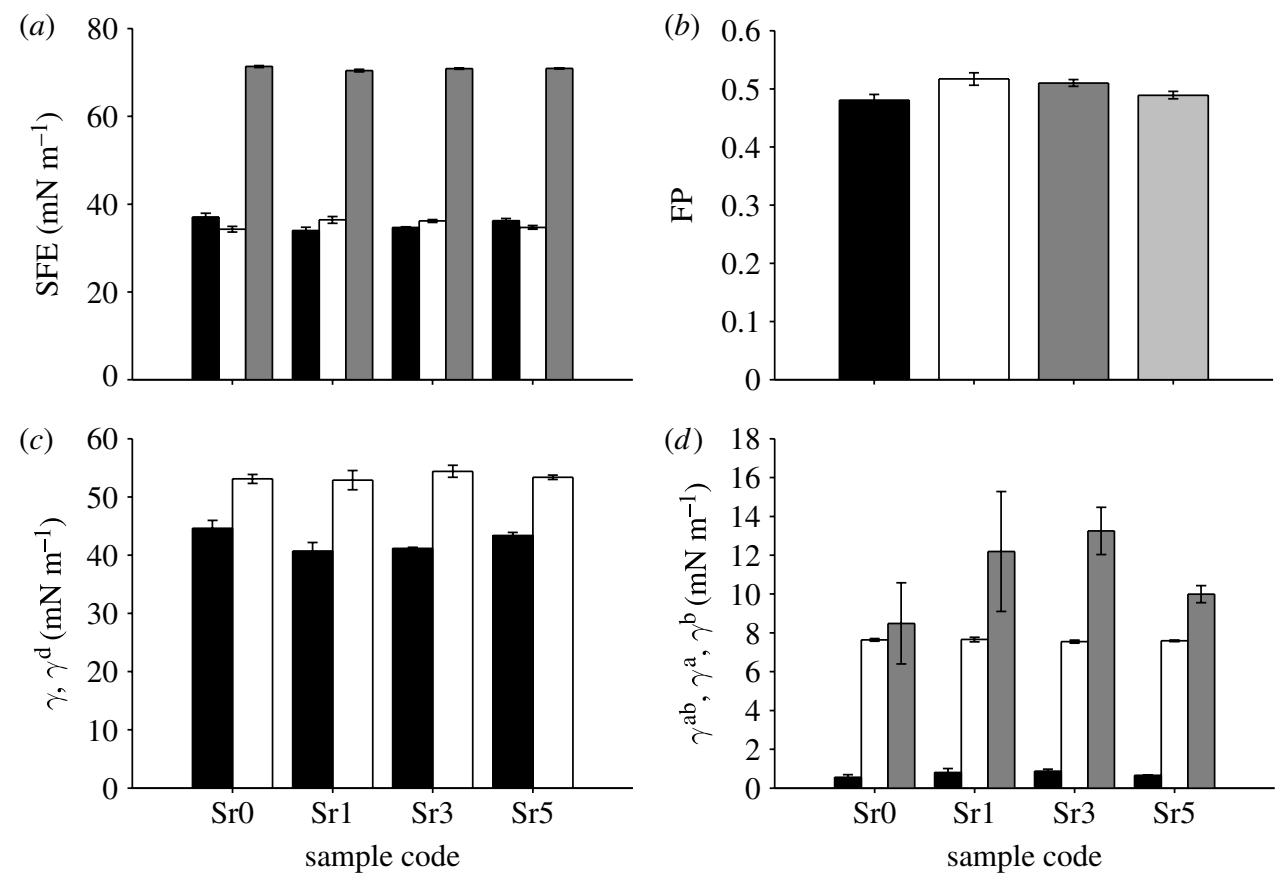

Figure 7. Results of SFE calculations using the OW method: (a) SFE and its dispersive and polar components (black bars, SFE ${ }^{\mathrm{d}}$; light grey bars, $\mathrm{SFE}^{\mathrm{P}}$; dark grey bars, $\left.\mathrm{SFE}^{\text {tot }}\right)$ and $(b) \mathrm{FP}$. Results of SFE calculation using VO method: $(c)$ total and dispersive component of the SFE (black bars, $\gamma^{\delta}$; light grey bars, $\gamma$ ) and $(d)$ acidic, basic and acid-base components of the SFE (black bars, $V^{\prime \prime \prime} \gamma^{\mathrm{a}}\left(V^{\prime \prime \prime} \mathrm{mN} \mathrm{m}^{-1}\right)$; light grey bars, $V^{\prime \prime \prime} \gamma^{\mathrm{b}}\left(V^{\prime \prime \prime} \mathrm{mN} \mathrm{m}^{-1}\right)$; dark grey bars, $\gamma^{\mathrm{ab}}\left(\mathrm{mN} \mathrm{m}^{-1}\right)$.
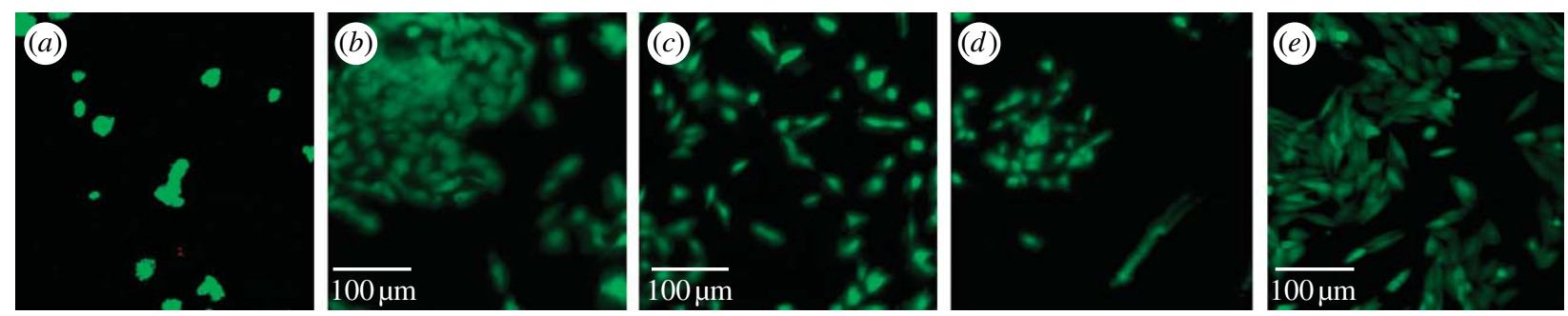

Figure 8. Confocal images of both controls ( $(a)$ CNP and $(e)$ Thermanox) compared with those showing viability of HOS cells seeded on the surface of glass discs of $(b)$ CNPSr1, $(c)$ CNPSr3 and $(d)$ CNPSr5 after 24 hours of culture.

These results suggest that the dominant factor affecting $\mathrm{Na}^{+}$release is the overall degradation rate of the glass, not the $\mathrm{Na}_{2} \mathrm{O}$ content. Hence, since the CNPSr1 glass showed the highest degradation rate, it also exhibited the highest level of $\mathrm{Na}^{+}$release. The $\mathrm{Ca}^{2+}$ ion release followed a similar trend to the $\mathrm{Na}^{+}$ion release. Addition of $1 \mathrm{~mol} \% \mathrm{SrO}$ increased the $\mathrm{Ca}^{2+}$ release relative to the $\mathrm{CNP}$ glass, but further additions of $\mathrm{SrO}$ of 3 and $5 \mathrm{~mol} \%$ reduced the rate of $\mathrm{Ca}^{2+}$ release to below that of the SrO-free glass. These results suggest that, as with the $\mathrm{Na}^{+}$release, the release of $\mathrm{Ca}^{2+}$ ions is strongly influenced by the overall degradation rate of the glass. By contrast, the release of $\mathrm{Sr}^{2+}$ ions was strongly correlated with the $\mathrm{SrO}$ content of the glasses.

Regarding the anion release data, the highest release was observed for the $\mathrm{P}_{3} \mathrm{O}_{9}^{3-}$ anion. This suggested that a significant concentration of the $\mathrm{P}_{3} \mathrm{O}_{9}^{3-}$ anion was present in the original sample. The lowest release was observed for the $\mathrm{P}_{2} \mathrm{O}_{7}^{4-}$ ions; similar results have been reported in previous work (Abou Neel et al. 2005a; Abou Neel \& Knowles 2007). In general, the release of all the anionic species measured followed the same trend as the glass degradation.
The changes in degradation associated with the glass composition were reflected not only in the concentration and rate of ions released but also in the changes in $\mathrm{pH}$ of the surrounding medium. As mentioned previously, the CNPSr1 glasses, having the highest degradation rate, displayed the greatest decrease $(4.92 \pm 0.06)$ in $\mathrm{pH}$ of the surrounding medium from the initial value of $7 \pm 0.1$. Moreover, the smallest reduction in $\mathrm{pH}$ was observed for the $\mathrm{CNP}$ glasses that showed the lowest degradation rate while both CNPSr3 and CNPSr5 glasses caused an intermediate pH change compared with the other compositions.

Numerous studies have demonstrated that the wettability of the surface has an influence on biological properties of biomaterials and cellular behaviour on the surface (Ponsonnet et al. 2003; Wirth et al. 2005, 2008; Yeung et al. 2008). However, it was shown to be more important to compare SFE and its components (especially the polar one), since they correlate to the cell adhesion and proliferation. Maximum cellular adhesion was previously observed when FP was equal to 0.3 (Hallab et al. 1995), and it was also shown that the lower the FP, the better the fibroblast proliferation. 
Furthermore, poor cell spreading was observed on low SFE materials (Schakenraad et al. 1988). In this study, the highest total SFE and the lowest FP were observed for CNP and CNPSr5 glasses. However, FP values were much higher than 0.3, and also they still showed no significant differences from CNPSr1 and CNPSr3 regarding the SFE and FP. This suggests that these glasses may not have surfaces that will encourage cells to attach and proliferate. This finding was also confirmed by the cell viability study, where these glasses showed lower or comparable viability up to 24 hours of culture, but, after that period, no cells could be detected. Regardless of these findings, the incorporation of strontium into these glasses improved the cellular response by increasing the number of cells attached to the surface and this also can be confirmed from the morphology of cells. Therefore, the reduced viability could not be due to the presence of strontium but was due to the very high degradation nature of these glasses, since the glass surfaces are not stable for cells to attach. Results obtained from both OW and VO methods were in agreement. Higher dispersive and lower polar components were observed for the CNP and CNPSr5 glasses. However, the basic component of the results of the acid-base calculation was the same for all samples, although differences were observed in the acid component, which was lower for the CNP and CNPSr5 samples. The acid components for all of the samples were significantly lower than that of the base, which suggested low acidic character of the surface. It can be concluded that from a thermodynamic point of view addition of $\mathrm{SrO}$ had no significant effect on the SFE components.

\section{CONCLUSIONS}

Substitution of $\mathrm{Na}_{2} \mathrm{O}$ with $\mathrm{SrO}$ from 0 to $5 \mathrm{~mol} \%$ produced a significant increase in density, glass transition temperature and degradation rate of these glasses. The increase in degradation rate was also confirmed by the levels of both cation $\left(\mathrm{Na}^{+}\right.$and $\mathrm{Ca}^{2+}$ ) and anion $\left(\mathrm{PO}_{4}^{3-}, \mathrm{P}_{2} \mathrm{O}_{7}^{4-}, \mathrm{P}_{3} \mathrm{O}_{9}^{3-}\right.$, and $\left.\mathrm{P}_{3} \mathrm{O}_{10}^{5-}\right)$ release from these glasses, and in turn by changes in the $\mathrm{pH}$ of the surrounding medium. $\mathrm{Sr}^{2+}$ release, however, was directly related to the amount of $\mathrm{SrO}$ in the glass and not to the degradation rate.

${ }^{31} \mathrm{P}$ MAS NMR results showed that, as the $\mathrm{Sr}^{2+}$ content was increased, the amount of $Q^{2}$ phosphorus decreased slightly, resulting in a slight increase in the number of $Q^{1}$ and $Q^{3}$ environments. ${ }^{23} \mathrm{Na}$ MAS NMR results suggested that the sodium environment was not significantly affected by increasing the $\mathrm{Sr}^{2+}$ content. A shift in the FTIR frequency of the $\nu_{\text {as }}(\mathrm{P}-\mathrm{O}-\mathrm{P})$ mode to higher energy has been observed with the replacement of $\mathrm{Na}^{+}$with higher field strength $\mathrm{Sr}^{2+}$ ions, which is associated with the shortening of the phosphorus to bridging oxygen distance and consequent strengthening of this bond. Moreover, the general broadening of the spectral features with $\mathrm{Sr}^{2+}$ content is most probably due to the increased variation of the phosphate-cation bonding interactions caused by the introduction of the third cation. It is perhaps this increased disorder or the fact that the Sr-containing glasses have higher $\mathrm{Na}_{2} \mathrm{O}$ than expected that causes the increased solubility of these glasses compared with the CNP glass.

Analysis of thermodynamic aspects of the surfaces, based on SFE evaluations, revealed no significant influence of strontium on SFE components, especially FP. However, incorporation of $\mathrm{Sr}^{2+}$ produced glasses with better cellular response than $\mathrm{Sr}^{2+}$-free glasses, but relatively lower cellular response than the positive control. This lower response could be due to the high degradation nature of these glasses and not due to the presence of strontium since the $\mathrm{Sr}^{2+}$-free glasses showed lower degradation but still showed the worst cellular response. Therefore, in our future work, we will tailor the chemistry to get glasses with relatively lower degradation and still incorporating $\mathrm{Sr}^{2+}$ as a means of improving the biocompatibility.

The authors would like to acknowledge the EPSRC (Grant nos. EP/C004671/1 \& EP/C004698/1 \& EP/C515560/1) for providing the funds to conduct this work. M.E.S. thanks the EPSRC and University of Warwick for partially supporting the NMR equipment at Warwick.

\section{REFERENCES}

Abou Neel, E. A. \& Knowles, J. C. 2008 Physical and biocompatibility studies of novel titanium dioxide doped phosphate-based glasses for bone tissue engineering applications. J. Mater. Sci. Mater. Med. 19, 377-386. (doi:10.1007/s10856-007-3079-5)

Abou Neel, E. A., Ahmed, I., Pratten, J., Nazhat, S. N. \& Knowles, J. C. $2005 a$ Characterisation of antimicrobial copper releasing degradable phosphate glass fibres. Biomaterials 26, 2247-2254. (doi:10.1016/j.biomaterials.2004. 07.024)

Abou Neel, E. A., Ahmed, I., Blaker, J. J., Bismarck, A., Boccaccini, A. R., Lewis, M. P., Nazhat, S. N. \& Knowles, J. C. $2005 b$ Effect of iron on the surface, degradation and ion release properties of phosphate-based glass fibres. Acta Biomater. 1, 553-563. (doi:10.1016/j.actbio.2005.05.001)

Abou Neel, E. A., Mizoguchi, T., Ito, M., Bitar, M., Salih, V. \& Knowles, J. C. 2007 In vitro bioactivity and gene expression by cells cultured on titanium dioxide doped phosphate-based glasses. Biomaterials 28, 2967-2977. (doi:10.1016/j.biomaterials.2007.03.018)

Abou Neel, E. A., O'Dell, L. A., Smith, M. E. \& Knowles, J. C. 2008 Processing, characterisation, and biocompatibility of zinc modified metaphosphate based glasses for biomedical applications. J. Mater. Sci. Mater. Med. 19, 1669-1679. (doi:10.1007/s10856-007-3313-1)

Ahmed, I., Collins, C. A., Lewis, M. P., Olsen, I. \& Knowles, J. C. 2004 Processing, characterisation and biocompatibility of iron-phosphate glass fibres for tissue engineering. Biomaterials 25, 3223-3232. (doi:10.1177/0885328205049396)

Ahmed, I., Lewis, M. P., Nazhat, S. N. \& Knowles, J. C. 2005 Quantification of anion and cation release from a range of ternary phosphate-based glasses with fixed $45 \mathrm{~mol} \% \mathrm{P}_{2} \mathrm{O}_{5}$. J. Biomater. Appl. 20, 65-80. (doi:10.1016/j.biomaterials. 2003.10.013)

Bitar, M., Salih, V., Mudera, V., Knowles, J. C. \& Lewis, M. P. 2004 Soluble phosphate glasses: in vitro studies using human cells of hard and soft tissue origin. Biomaterials $\mathbf{2 5}$, 2283-2292. (doi:10.1016/j.biomaterials.2003.08.054)

Brow, R. K., Kirkpatrick, R. J. \& Turner, G. L. 1990 The short range structure of sodium phosphate glasses. I. MAS NMR studies. J. Non-Cryst. Solids 116, 39-45. (doi:10. 1016/0022-3093(90)91043-Q) 
Byun, J. O., Kim, B. H., Hong, K. S., Jung, H. J., Lee, S. W. \& Izyneev, A. A. 1995 Properties and structure of RO- $\mathrm{Na}_{2} \mathrm{O}-$ $\mathrm{Al}_{2} \mathrm{O}_{3}-\mathrm{P}_{2} \mathrm{O}_{5}(\mathrm{R}=\mathrm{Mg}, \mathrm{Ca}, \mathrm{Sr}, \mathrm{Ba})$ glasses. J. Non-Cryst. Solids 190, 288-295. (doi:10.1016/0022-3093(95)00280-4)

Drake, C. F. 1985 Continuous and pulsed delivery of bioactive materials using composite system based on inorganic glasses. Consultation on Immunomodulation, Bellagio, Italy, 16-18 April.

Drake, C. F. \& Allen, W. M. 1985 The use of controlledrelease glasses for the controlled delivery of bioactive materials. Biochem. Soc. Trans. 13, 516-520.

Fletcher, J. P., Kirkpatrick, R. J., Howell, D. \& Risbud, S. H. 1993 P-31 magic-angle-spinning nuclear-magnetic-resonance spectroscopy of calcium-phosphate glasses. J. Chem. Soc. Farad. Trans. 89, 3297-3299. (doi:10.1039/ft9938903297)

Franks, K., Abrahams, I. \& Knowles, J. C. 2000 Development of soluble glasses for biomedical use. Part I. In vitro solubility measurement. J. Mater. Sci. Mater. Med. 11, 609-614. (doi:10.1023/A:1008949527695)

Franks, K., Salih, V., Knowles, J. C. \& Olsen, I. 2002 The effect of $\mathrm{MgO}$ on the solubility behaviour and cell proliferation in a quaternary soluble phosphate based glass system. J. Mater. Sci. Mater. Med. 13, 549-556. (doi:10.1023/A:1015122709576)

Giammarile, F., Mognetti, T., Blondet, C., Desuzinges, C. \& Chauvot, P. 1999 Bone pain palliation with ${ }^{85} \mathrm{Sr}$ therapy. J. Nucl. Med. 40, 585-590.

Gough, J. E., Christian, P., Scotchford, C. A., Rudd, C. D. \& Jones, I. A. 2002 Synthesis, degradation, and in vitro cell responses of sodium phosphate glasses for craniofacial bone repair. J. Biomed. Mater. Res. 59, 481-489. (doi:10.1002/ jbm.10020)

Hallab, N., Bundy, K., O'Connor, K., Clark, R. \& Moses, R. 1995 Cell adhesion to biomaterials: correlations between surface charge, surface roughness, adsorbed protein and cell morphology. J. Long-Term Effects Med. Implants $\mathbf{5 3}$ 209-231.

Ilieva, D., Jivov, B., Bogachev, G., Petkov, C., Penkov, I. \& Dimitriev, Y. 2001 Infrared and Raman spectra of $\mathrm{Ga}_{2} \mathrm{O}_{3}-$ $\mathrm{P}_{2} \mathrm{O}_{5}$ glasses. J. Non-Cryst. Solids 283, 195-202. (doi:10. 1016/S0022-3093(01)00361-1)

Kemp T. F. 2004 High field solid state ${ }^{27} \mathrm{Al}$ NMR of ceramics and glasses, Masters Thesis, University of Warwick.

Knowles, J. C. 2003 Phosphate based glasses for biomedical applications. J. Mater. Chem. 13, 2395-2401. (doi:10. 1039/b307119g)

Knowles, J. C., Franks, K. \& Abrahams, I. 2001 Investigation of the solubility and ion release in the glass system $\mathrm{K}_{2} \mathrm{O}$ $\mathrm{Na}_{2} \mathrm{O}-\mathrm{CaO}-\mathrm{P}_{2} \mathrm{O}_{5}$. Biomaterials 22, 3091-3096. (doi:10. 1016/S0142-9612(01)00057-6)

Kohn, S. C., Smith, M. E., Dirken, P. J., Van Eck, E. R. H., Kentgens, A. P. M. \& Dupree, R. 1998 Sodium environments in dry and hydrous albite glasses. Improved ${ }^{23} \mathrm{Na}$ solid state NMR data and their implications for water dissolution mechanisms. Geochim. Cosmoschim. Acta 62, 79-87. (doi:10.1016/S0016-7037(97)00318-9)

KSV Instruments 2007 Surface free energy-background, calculation and examples by using contact angel measurements. Application note \#108. Helsinki, Finland: KSV Instruments, Ltd.

Llinas, P., Masella, M., Stigbrand, T., MéNez, A., Stura, E. A. \& Le Du, M. H. 2006 Structural studies of human alkaline phosphatase in complex with strontium: implications for its secondary effect in bones. Protein Sci. 15, 1691-1700. (doi:10.1110/ps.062123806)

MacKenzie, K. J. D. \& Smith, M. E. 2002 Multinuclear solid state NMR of inorganic materials. Oxford, UK: Pergamon Press.
Marie, P. J. 2005 Strontium ranelate: a novel mode of action optimizing bone formation and resorption. Osteo. Int. 16, S7-S10. (doi:10.1007/s00198-004-1753-8)

Massiot, D. et al. 2002 Modelling one- and two-dimensional solid state NMR spectra. Magn. Reson. Chem. 40, 70-76. (doi:10.1002/mrc.984)

Meunier, P. J. et al. 2004 The effects of strontium ranelate on the risk of vertebral fracture in women with postmenopausal osteoporosis. New Engl. J. Med. 350, 459-468. (doi:10.1056/NEJMoa022436)

Moustafa, Y. M. \& El-Egili, K. 1998 Infrared spectra of sodium phosphate glasses. J. Non-Cryst. Solids 240, 144-153. (doi:10.1016/S0022-3093(98)00711-X)

O'Dell, L. A., Savin, S. L. P., Chadwick, A. V. \& Smith, M. E. 2007 A multinuclear magic angle spinning NMR investigation of sol-gel and ball-milled nanocrystalline $\mathrm{Ga}_{2} \mathrm{O}_{3}$. Appl. Magn. Reson. 32, 527-546. (doi:10.1007/s00723-0070036-x)

Pickup, D. M., Ahmed, I., Guerry, P., Knowles, J. C., Smith, M. E. \& Newport, R. J. 2007 The structure of phosphate glass biomaterials from neutron diffraction and ${ }^{31} \mathrm{P}$ nuclear magnetic resonance data. J. Phys. Condens. Matter 19, 415 116. (doi:10.1088/0953-8984/19/41/415116)

Ponsonnet, L., Reybier, K., Jaffrezic, N., Comte, V., Lagneau, C., Lissac, M. \& Martelet, C. 2003 Relationship between surface properties (roughness, wettability) of titanium and titanium alloys and cell behaviour. Mater. Sci. Eng. C 23, 551-560. (doi:10.1016/S0928-4931(03)00033-X)

Rajendran, V., Gayathri Devi, A. V., Azooz, M. \& El-Batal, F. H. 2006 Physicochemical studies of phosphate based $\mathrm{P}_{2} \mathrm{O}_{5}-\mathrm{Na}_{2} \mathrm{O}-\mathrm{CaO}-\mathrm{TiO}_{2}$ glasses for biomedical applications. J. Non-Cryst. Solids 353, 77-84. (doi:10.1016/ j.jnoncrysol.2006.08.047)

Reginster, J. Y. et al. 2005 Strontium ranelate reduces the risk of nonvertebral fractures in postmenopausal women with osteoporosis: treatment of peripheral osteoporosis (TROPOS) study. J. Clin. Metab. 90, 2816-2822. (doi:10. 1210/jc.2004-1774)

Saarto, T., Janes, R., Tenhunen, M. \& Kouri, M. 2002 Palliative radiotherapy in the treatment of skeletal metastases. Eur. J. Pain. 6, 323-330. (doi:10.1016/S10 90-3801(02)00028-9)

Salih, V., Franks, K., James, M., Abrahams, I., Hastings, G. W., Knowles, J. C. \& Olsen, I. 2000 Development of soluble glasses for biomedical use. Part 2. The biological response of human osteoblast cell lines to phosphate-based soluble glasses. J. Mater. Sci. Mater. Med. 11, 615-620. (doi:10.1088/1748-6041/2/1/003)

Salih, V., Patel, A. \& Knowles, J. C. 2007 Zinc containing phosphate-based glasses for tissue engineering. Biomed. Mater. 2, 1-11. (doi:10.1023/A:1008901612674)

Schakenraad, J. M., Busscher, H. J., Wildevuur, Ch. R. H. \& Arends, J. 1988 Thermodynamic aspects of cell spreading on solid substrata. J. Cell Biophys. 13, 75-91.

Shah, R., Sinanan, A. C. M., Knowles, J. C., Hunt, N. P. \& Lewis, M. P. 2005 Craniofacial muscle engineering using a 3-dimensional glass fibre constructs. Biomaterials 26, 1497-1505. (doi:10.1016/j.biomaterials.2004.04.049)

Shih, P.-Y. \& Shiu, H.-M. 2007 Properties and structural investigations of UV-transmitting vitreous strontium zinc metaphosphate. Mater. Chem. Phys. 106, 222-226. (doi:10.1016/j.matchemphys.2007.05.038)

Skelton, K. L., Glenn, J. V., Clark, S. A., Georgiou, G., Valappil, S. P., Knowles, J. C., Nazhat, S. N. \& Jordan, G. R. 2007 Effect of ternary phosphate-based glass compositions on osteoblast-like proliferation, differentiation and death in vitro. Acta Biomater. 3, 563-572. (doi:10.1016/j.actbio.2006.11.008) 
Smith, M. E. \& Van Eck, E. R. H. 1999 Recent advances in experimental solid state NMR methodology for half-integer spin quadrupolar nuclei. Prog. NMR Spectrosc. 34, 159-201. (doi:10.1016/S0079-6565(98) 00028-4)

Velli, L. L., Varsamis, C. P. E., Kamitsos, E. I., Moncke, D. \& Ehrt, D. 2005 Structural investigation of metaphosphate glasses. Phys. Chem. Glasses 46, 178-181.

Wirth, C., Comte, V., Lagneau, C., Exbrayat, P., Lissac, M., Jaffrezic-Renault, N. \& Ponsonnet, L. 2005 Nitinol surface roughness modulates in vitro cell response: a comparison between fibroblasts and osteoblasts. Mater. Sci. Eng. C 25, 51-60. (doi:10.1016/j.msec.2004.06.001)

Wirth, C., Grosgogeat, B., Lagneau, C., Jaffrezic-Renault, N. \& Ponsonnet, L. 2008 Biomaterial surface properties modulate in vitro rat calvaria osteoblasts response: Roughness and or chemistry? Mater. Sci. Eng. C 28, 990-1001. (doi:10.1016/j.msec.2007.10.085)

Wren, A., Boyd, D. \& Towler, M. R. 2008 The processing, mechanical properties and bioactivity of strontium based glass polyalkenoate cements. J. Mater. Sci. Mater. Med. 19, 1737-1743. (doi:10.1007/s10856-007-3287-z)

Yeung, K. W. K. et al. 2008 New plasma surface-treated memory alloys: towards a new generation of 'smart' orthopaedic materials. Mater. Sci. Eng. C 28, 454-459. (doi:10.1016/j.msec.2007.04.023)

Yu, X., Day, D. E., Long, G. J. \& Brow, R. K. 1997 Properties and structure of sodium-iron phosphate glasses. J. NonCryst. Solids 215, 21-31. (doi:10.1016/S0022-3093(97) 00022-7) 